\title{
A new species of Nematoceras and characterisation of $N$. dienemum (Orchidaceae), both from subantarctic Macquarie Island
}

\author{
M.A. Clements and D.L. Jones \\ Centre for Plant Biodiversity Research, Australian National Herbarium, G.P.O. Box 1600, \\ Canberra, A.C.T., 2601, Australia
}

\begin{abstract}
Two species of Nematoceras (Orchidaceae) from subantarctic Macquarie Island are characterised, illustrated and details of distribution and ecology are provided. Nematoceras sulcatum M.A.Clem. et D.L.Jones, recently identified by field studies and confirmed by comparative morphological and DNA analyses, is described as new.
\end{abstract}

\section{Introduction}

Macquarie Island is an isolated subantarctic island in the Southern Ocean located at $54^{\circ} 30^{\prime} \mathrm{S}, 158^{\circ} 56^{\prime} \mathrm{E}, \mathrm{c} .1500 \mathrm{~km}$ SSE of Tasmania, approximately halfway to the Antarctic continent. The island is approximately $34 \mathrm{~km}$ long and up to $5.5 \mathrm{~km}$ wide with an undulating north-south trending plateau $200-350 \mathrm{~m}$ above sea level. It was formed by tectonic uplift of the ocean floor 600,000-700,000 y.b.p. and has never been connected to any other land mass (Adamson et al. 1996). The flora of Macquarie Island, which has been the subject of much research, shows affinities with that of other southern ocean islands, and has established after long-distance transoceanic dispersal of seeds and spores (Bergstrom \& Selkirk 1987). The flora is restricted to bryophytes, lichens and low-growing vascular plants, and distinct vegetation communities are found on the coastal terraces, coastal slopes and plateau uplands (Selkirk et al. 1990).

The first record of Orchidaceae from Macquarie Island was a species of Corybas (Acianthinae: Diurideae) discovered on the raised beach terraces of the north-west coast (Brown et al. 1978) and identified by the New Zealand botanist, Elizabeth Edgar, as Corybas macranthus. It was subsequently shown to be morphologically distinct from C. macranthus and was described as C. dienemus D.L.Jones (Jones 1993). Soon after in a detailed study of Diurideae but in particular Acianthinae, based on analysis of morphological and sequence data, using the internal transcribed spacer (ITS) region of the 18-26S nuclear ribosomal DNA, (Clements et al. 2002), the genus Nematoceras was re-instated as distinct from Corybas. Jones et al. (2002) subsequently transferred 
C. dienemus to the genus Nematoceras, viz. N. dienemum (D.L.Jones) D.L.Jones, M.A.Clem. et Molloy (as “dienema"). Nematoceras is recognised as distinct from Corybas by possession of: flowers with relatively narrow dorsal sepal; lateral sepals and petals subsimilar, long, narrow and erect; labellum large, tubular or flared, auricles open-ended; callus of a thickened medial ridge; and column short, squat and lacking a swollen ventral pad (Jones et al. 2002).

During recent field work on Macquarie Island, leaf material of a possible second species of Nematoceras was collected on the upland plateau terraces of the Sawyer Creek valley. A study of the herbarium collections held at the Tasmanian Herbarium (HO) and an analysis of the Internal Transcribed Spacer (ITS) DNA region, where there was a difference of 17 bases (2.5\%), suggested the existence of a second species on the island (Mackenzie et al. 2005) details of which will be published in a companion paper (Clements et al. 2007, in press). Flowering material located during later field work confirmed the distinctiveness of this second Nematoceras. The new species is described and illustrated here with supplementary ecological data and the opportunity is also taken to fully characterise and illustrate $N$. dienemum, the species originally described from Macquarie Island.

\section{Taxonomy}

Nematoceras sulcatum M.A.Clem. \& D.L.Jones, sp. nov.

Affinis Nematoceras trilobo Hook.f., sed flore exorienti infra petiolo fere medio, erecto; petalis et sepalis lateralibus filiformibus, erectis, sepalis longitudinibus fere duplo petalis; sepalo dorsali anguste spathulato obtuso cucullato, atropurpureo; labello minor, umbone centrali sulcato citreo; marginibus labelli leviter incurvatis, atroviolaceis, ad apicem minute erosis, differt.

Holotype: Macquarie Island, 54 30'S, 158 56'E, G. Copson \& G. Leaman s.n., 23 Nov 1980 (HO 91827).

Terrestrial tuberous herb, glabrous, deciduous, forming clonal colonies. Tubers globose to ellipsoid, 1-7 mm long, 1-6 mm wide. Stolonoid roots $40-90 \mathrm{~mm}$ long, c. $1 \mathrm{~mm}$ thick. Leaf solitary, held at the substrate surface, flat to shallowly concave, petiolate; lamina orbicular, 12-20 mm long, 12-20 mm wide, light green with visible veins above, silvery green beneath; apiculate. Petiole arising below substrate surface, fleshy, 12-16 mm long, 1.5-2 mm thick, slightly recurved. Pedicel green, 5-7 mm long, 1-1.5 mm thick, fleshy. Floral bract erect, membranous, not sheathing, lanceolate when flattened, 5-8 mm long, 1.5-2 mm wide. Ovary erect, asymmetric, fleshy, 5-8 long, 1-1.5 mm wide. Inflorescence, arising c. halfway along the petiole below the leaf lamina. Flower erect, with most parts dark red, 25-30 long, 10-14 mm wide. Dorsal sepal spathulate when flattened, 14-17 mm long, 5-6.5 mm wide, incurved, cucullate over most of the labellum, dark red, lighter and striate towards the base, apex apiculate. Lateral sepals exceeding the dorsal sepal, erect to spreading, filiform, 27-30 mm long, c. $0.8 \mathrm{~mm}$ wide at the base, dark red, lighter towards the base. Petals erect to spreading, filiform, $11-13 \mathrm{~mm}$ long, c. $0.6 \mathrm{~mm}$ wide, dark red, lighter towards the base. Labellum mostly hidden by the dorsal sepal, dark red; labellum tube 5-7 mm long then abruptly deflexed through $180^{\circ}$ and expanded into the lamina; lamina broadly ovate to orbicular, $12-15 \mathrm{~mm}$ long, 8-10 mm wide, the margins incurved, irregular to denticulate; boss prominent, cream to pale yellow, with a deep central groove. Column erect, $2.5-3 \mathrm{~mm}$ long, c. $0.7 \mathrm{~mm}$ 
wide, obscurely winged. Anther porrect, c. $1.2 \mathrm{~mm}$ long, erostrate. Pollinia cream to white, sessile on an ovate viscidium. Stigma circular, c. $0.8 \mathrm{~mm}$ wide, concave, margins entire. Capsule not seen. (Fig. 1).

Etymology: from the Latin sulcatus grooved, furrowed, channelled, in reference to the prominent groove in the labellum boss.

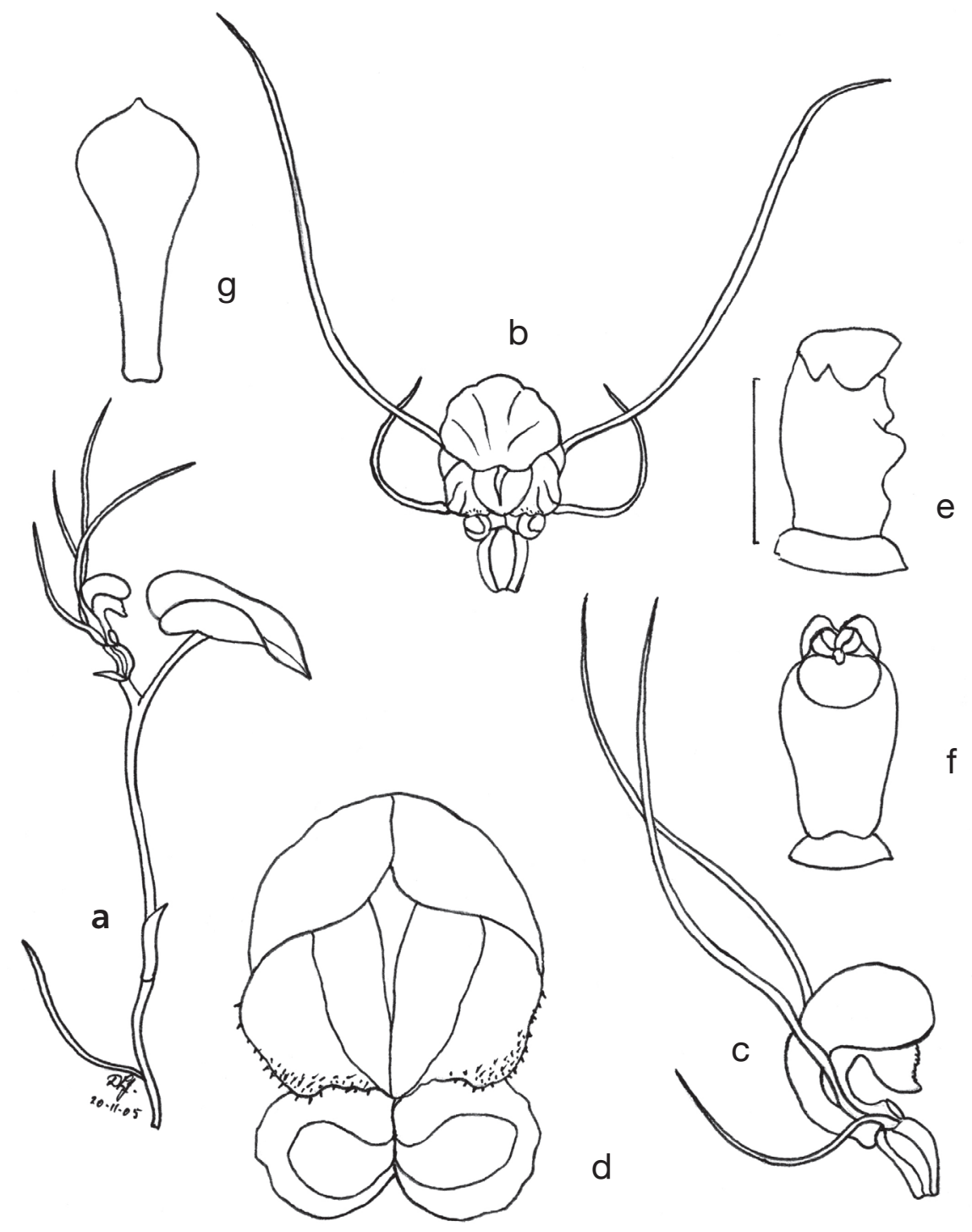

Fig. 1. Nematoceras sulcatum. a, flowering plant from side; b, flower from front; $\mathbf{c}$, flower from side; $\mathbf{d}$, flower from front, lateral sepals and petals removed; e, column from side; f, column from front; g, dorsal sepal flattened (all from Carmichael ORG 5135). Scale bar: a $=20 \mathrm{~mm}$; b, c, $g=10 \mathrm{~mm} ; \mathrm{d}=8 \mathrm{~mm} ; \mathrm{e}, \mathrm{f}=2 \mathrm{~mm}$. Illustration by D.L. Jones. 
Distribution and ecology: endemic to Macquarie Island where it occurs on part of the plateau uplands, growing in wet grassy seepage areas along the eastern side of the Sawyer Creek Valley at $80-150 \mathrm{~m}$ alt. One site is c. $1.2 \mathrm{~km}$ south of the Green Gorge Mire alongside the old Overland walking track; another site occurs to the west of the Overland walking track 0.75 kilometres north of Pyramid Lake. The vegetation is mainly short grassland dominated by Festuca contracta, Agrostis magellanica and Luzula crinita, with mosses and liverworts. The water table is close to the surface but there is some drainage due to the slopes of the terraces alongside Sawyer Creek. Flowering period: November-December.

Recognition: Nematoceras sulcatum is readily distinguished from $N$. dienemum by its dark red flowers, obovate-spathulate dorsal sepal that is strongly incurved and cucullate over the labellum and a broadly ovate to orbicular labellum lamina with a prominent cream to pale yellow deeply grooved boss. The new species is probably most closely allied to the New Zealand species N. trilobum Hook.f., from which it can be distinguished by the dark red flower arising from below the leaf lamina, narrowly obovate-spathulate dorsal sepal, and smaller ovate-orbicular labellum with a denticulate apical margin.

Notes: Nematoceras sulcatum is the second orchid species described from Macquarie Island and field studies suggest that each species may occupy a different habitat (see notes under Nematoceras dienemum). It is also worth noting that, although the viscidium was reported as lost in the common ancestor of "Corysanthinae" (which includes Corybas and Nematoceras) plus Cyrtostylis (Clements et al. 2002), correctly this loss only occurred in Cyrtostylis.

Other specimens examined: Macquarie Island: without specific locality, 22 Nov 1980, Copson \& Leaman s.n. (HO 91825); Green Gorge, 6 Nov 1980, G. Copson s.n. (HO 91831); Sawyer Creek, 543'ㄹ'25.0"S, 158 53'00.7"E, 16 Feb 2004, Skotnicki, Mackenzie \& Selkirk K632 (CANB, sterile); Sawyer Creek, 54 38'24.5"S, 158 53'03.7"E, 16 Feb 2004, Skotnicki, Mackenzie \& Selkirk K633 (CANB sterile); North of Pyramid Peak, 5439'08.9"S, 15852'46.8"E, 3 Mar 2004, Skotnicki, Mackenzie \& Selkirk K1358 (CANB sterile); site K632, Pyramid Peak, Jan 2005, Carmichael (ORG 5135) (CANB).

Nematoceras dienemum (D.L.Jones) D.L.Jones, M.A.Clem. et Molloy, Orchadian 13(10): 449 (30 Jan. 2002) (as 'dienema')

Corybas dienemus D.L.Jones, Fl. Australia 50: 572, f. 90 F-G (1993).

Corybas macranthus auct. non (Hook.f.) Rchb.f.: M.J.Brown et al., New Zealand J. Bot. 16: 405-407 (1978).

Holotype: 'N of Bauer Bay, Macquarie Is.', J.R. Croft 10445, 27 Nov.1989 (CANB!); isotypes (HO!, MEL!, NSW!, WELT!).

Terrestrial tuberous herb, glabrous, deciduous, forming small clonal groups. Tubers globose to ellipsoid, 1-5 $\mathrm{mm}$ long, 1-5 $\mathrm{mm}$ wide. Stolonoid roots 5-35 $\mathrm{mm}$ long, c. $1 \mathrm{~mm}$ thick. Leaf solitary, held at the substrate surface, cupulate, petiolate; lamina orbicular, 12-20 mm long, 14-23 mm wide, dark green above, silvery green beneath, thick, fleshy; base cordate; apex apiculate. Petiole arising below substrate surface, fleshy, 10-20 mm long, 1.5-2 mm thick. Pedicel vestigial, green, c. $1 \mathrm{~mm}$ long, $1-1.3 \mathrm{~mm}$ thick. Floral bract erect, membranous, sheathing, ovate-deltate when flattened, 5-6 mm long, 3-3.5 mm wide. Ovary erect, asymmetric, fleshy, 3-6 $\mathrm{mm}$ long, 2-2.5 $\mathrm{mm}$ wide. Inflorescence arising on the petiole. Flower erect, nestling in the leaf base, green with 
purplish-red markings, 25-30 $\mathrm{mm}$ long, 20-25 mm wide. Dorsal sepal incurved with a recurved apex, partially cucullate over the labellum, oblong when flattened, 12-15 mm long, 2.5-3 mm wide, with irregular dark striae; apex acute to acuminate with involute margins. Lateral sepals exceeding the dorsal sepal, erect, filiform, 30-33 mm long, c. 1.5 $\mathrm{mm}$ wide at the base, lightly twisted, with scattered dark marks. Petals erect to recurved, filiform, 23-25 mm long, c. $1.5 \mathrm{~mm}$ wide, with scattered dark marks. Labellum apex protruding, purplish red; labellum tube $3-5 \mathrm{~mm}$ long then abruptly recurved at $90^{\circ}$ and expanded into the lamina; lamina ovate, $6.5-7.5 \mathrm{~mm}$ long, $12-15 \mathrm{~mm}$ wide, the margins incurved, irregular to denticulate; boss not prominent, purplish red; apex shortly caudate. Column procumbent, 3-3.5 mm long, c. $2 \mathrm{~mm}$ wide, obscurely winged. Anther porrect, c. $1.3 \mathrm{~mm}$ long, erostrate, shortly dentiform. Pollinia cream to white, sessile on an elliptic viscidium. Stigma elliptical, c. $1.2 \mathrm{~mm}$ wide, concave, with strongly dentiform margins. Capsules ovoid, 9-11 mm long, 3-4 mm wide, held erect on a thickened peduncle 4-8 cm long. (Fig. 2).

Distribution and ecology: Nematoceras dienemum inhabits the lower coastal terraces $(<20 \mathrm{~m}$ above sea level) and the Green Gorge mire where the vegetation is dominated by bryophytes (mosses) which "float" on a waterlogged underlayer (featherbed). Flowering period: November- January. By contrast N. sulcatum has only been found in short grassland communities on the plateau uplands at $80-150 \mathrm{~m}$ above sea level.

Recognition: Nematoceras dienemum is readily distinguished from N. sulcatum by its green flowers with purplish-red markings, oblong dorsal sepal that is shallowly incurved with a recurved acute to acuminate apex with involute margins and an ovate labellum with an inconspicuous purplish-red boss.

Notes: the affinities of $N$. dienemum are unclear but probably lie with Nematoceras species from the South Island of New Zealand. The friable nature of the pollen suggests autogamy in this species. The dentiform margins of the stigma are an unusual and noteworthy feature.

Other specimens examined: Macquarie Island: without specific locality, 12 Nov 1980, Copson s.n. (HO 91824); Half Moon Bay, 12 Nov 1980, Copson s.n. (HO 91823); without specific locality, 24 Nov 1980, Copson \& Leaman s.n. (HO 91826); Green Gorge, 24 Feb 1980, Leaman \& Copson s.n. (HO 91829).

\section{Acknowledgments}

We thank the Curator of Tasmanian Herbarium (HO) for loan of the specimens. Mary Skotnicki, Patricia Selkirk, Anne Mackenzie, Noel Carmichael and Jenny Sheridan provided samples collected in 2004 with permission from Tasmanian Parks and Wildlife Service and from Tasmanian Resource Management and Conservation. Logistical support for fieldwork was provided by the Australian Antarctic Division. Geoff Copson kindly provided details of orchid localities on Macquarie Island for collection of the above samples.

\section{References}

Adamson DA, Selkirk PM, Price DM, Ward N \& Selkirk JM (1996) Pleistocene uplift and palaeoenvironments of Macquarie Island: evidence from palaeobeaches and sedimentary deposits. Papers and Proceedings of the Royal Society of Tasmania 130: 25-32. 


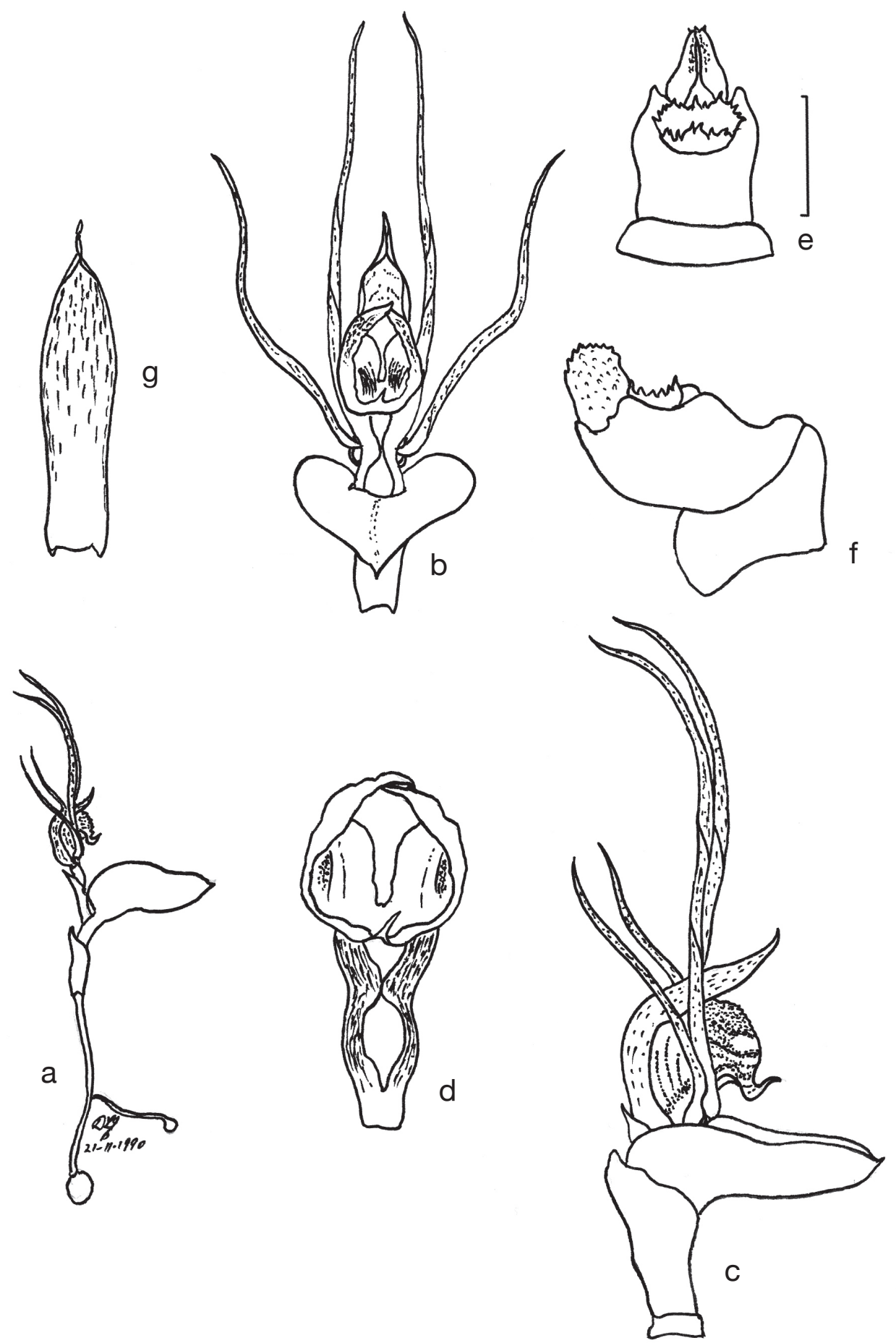

Fig. 2. Nematoceras dienemum. a, flowering plant from side; $\mathbf{b}$, leaf and flower from front; c, leaf and flower from side; $\mathbf{d}$, labellum from front; e. column from side; $\mathbf{f}$, column from front; g, dorsal sepal flattened (all from cult. ex Croft 10445). Scale bar: $a=20 \mathrm{~mm} ; \mathrm{b}, \mathrm{c}=10 \mathrm{~mm}$; $\mathrm{d}, \mathrm{g}=5 \mathrm{~mm} ; \mathrm{e}, \mathrm{f}=2 \mathrm{~mm}$. Illustration by D.L. Jones. 
Bergstrom DM \& Selkirk PM (1987) Reproduction and dispersal of mosses on Macquarie Island. Symposia Biologica Hungarica 35: 247-257.

Brown MJ, Jenkin JF, Brothers NP \& Copson GR (1978) Corybas macranthus (Hook.f.) Reichb. f. (Orchidaceae), a new record for Macquarie Island. New Zealand Journal of Botany 16: 405-407.

Clements MA, Jones DL, Sharma IK, Nightingale ME, Garratt MJ, Fitzgerald KJ, Mackenzie AM \& Molloy BPJ (2002) Phylogenetic systematics of the Diurideae (Orchidaceae) based on the ITS and 5.8S coding region of nuclear ribosomal DNA. Lindleyana 17: 135-171.

Clements MA, Mackenzie AM, Copson GR, Molloy BPJ, Carmichael N, Skotnicki, ML \& Selkirk PM (2007, in press) Biology and molecular phylogenetics of Nematoceras sulcatum, a second endemic orchid species from subantarctic Macquarie Island. Polar Biology.

Jones DL (1993) Orchidaceae (Macquarie Island). P. 572 in Hewson HJ \& Thompson HS (eds) Flora of Australia, vol. 50, Oceanic Islands, vol. 2. (Australian Government Publishing Service: Canberra)

Jones DL, Clements MA, Sharma IK, Mackenzie AM \& Molloy BPJ (2002) Nomenclatural notes arising from studies into the tribe Diurideae (Orchidaceae). Orchadian 13(10): 437-468.

Mackenzie AM, Carmichael N, Clements MA, Copson GR, Selkirk PM \& Skotnicki ML (2005a) Australia's Subantarctic Orchids. Pp 321-324 in Raynal-Roques A, Roguenant A \& Prat D (eds) Proceedings of the $18^{\text {th }}$ World Orchid Conference March 11-20, 2005, Dijon-France. (Naturalia: France)

Selkirk PM, Seppelt RD \& Selkirk DR (1990) Subantarctic Macquarie Island: environment and biology. (Cambridge University Press: Cambridge)

Manuscript received 16 June 2006, accepted 22 February 2007 